\title{
KEPEMIMPINAN STRATEGI "Konsep dan Implementasi Kepemimpinan Islami”
}

\section{Zaenul Iskandar}

Abstrak. Kepemimpinan strategi adalah upaya pengelolaan terencana dalam menjalankan organisasi. Strategi meliputi merencanakan, mengorganisir, mengarahkan, mengkordinir serta mengawasi, melanjutkan kegiatan dalam suatu organisasi agar tercapai tujuan organisasi secara efisien dan efektif, lebih dari itu bernilai ibadah mencapai kemulian, kehormatan, serta keridhaan Allah SWT. Implemntasi manajemen strategi dengan kendali syraiah akan membawa organisasi berorientasi pada pencapaian empat hal utama yaitu 1. Target hasil (profit materi dan banefit non materi); 2. Pertumbuhan (terus meningkat); 3. Keberlangsungan (dalam kurun waktu selama mungkin); 4. Keberkahan dan keridhaan Allah.

Keyword: kepemimpinan, strategi, islami

\section{PENDAHULUAN}

Setiap orang terlahir sebagai pemimpin, dalam skala yang lebih kecil dia menjadi pemimpin pada dirinya pribadi, sementara pada hal-hal yang besar dapat menjadi pemimpin dalam lembaga, perusahaan, organisasi dan sebagainya. Upaya melakasanakan kepemimpinannya maka dibutuhkan hal-hal yang dijadikan sebagai pedoman, alat, media, sarana, sember daya, kemampuan untuk mencapai sebuah tujuan dalam kepemimpinannya. Mengelola hal tersebut merupakan sebuah langkah dalam kepemimpinan stategi.

Istilah strategi pada mulanya digunakan dalam lingkup militer. Karena asal kata strategi dari bahsa Yunani yaitu strategos. Hari Purnomo dan Zulkieflimansyah (2005) mengungkapkan kata strageos sendiri berasal dari kata stratos yang berarti miiliter dan ag yang berarti memimpin. Dalam konstek awal strategi diartikan sebagai generalship atau sesuatu yang dikerjakan oleh para jendral dalam membuat rencana untuk menaklukkan musuh, dan memenangkan perang. Hal ini dilakukan karena untuk menaklukkan musuh diperlukan sebuah pemikiran yang strategik agar berhasil dengan baik. Istilah strategi dalam pengertian militer (peperangan) diperoleh pertama kali dipenghujung abad ke18 , ketika peperangan masih relatif sederhana dan terbatas.

Dalam pekermbangannya konsep strategi diadopsi pada dunia bisnis yang bergerak pada usaha (profit). Karena esensinya strategi adalah suatu "gaya" berfikir. Hal ini dapat dilihat dari ungkapan orang China " Pasar adalah medan perang". Mereka melihat kesamaan kebijakan dalam mengarahkan jendral di medan perang sama seperti kebijakan yang mengarahkan pebisnis di pasar. Schnaars (1991) sebagaimana dikemukakan Nurul saputra (2018) mengungkapkan bahwa perkembangan konsep strategi dalam dunia usaha atau bisnis secara formal muncul pada abad ke-19 pada perang dunia II yang ditandai dengan fase-fase perkembangan yaitu :

1. Budgeting dan overal strategy (strategi anggaran dan kontrol keuangan) pada masa 1950

2. Perencanaan jangka panjang (1960)

3. Formula planing (perencanaan strategi perusahaan) (1970)

4. Strategic thingking (maajemen strategi) (1980)

Menurut Sedarmayanti (2014) emberio dari perkembangan konsep manajemen strategi adalah pemikiran tentang sitem perencanaan strategi. Inti kegiatan perencanaan adalah menyusun program kerja yang jelas dan dapat diimplementasikan sehingga dapat menjamin keberlasungan dan perkembangan hidup organisasi dalam lingkungan yang senantiasa berubah. 
Konsep strategi dalam pengertian jangka panjang dikemukan sebagaimana Chandler (1962) menyebutkan bahawa strategi adalah tujuan jangka panjang dari suatu perusahaan, serta pendayagunaan dan alokasi sumber daya yang penting untuk mencapai tujuan tersebut. Pemahaman yang luas dan baik tetang suatu konsep strategi dan konsepkonsep lainnya yang berkaitan akan mewujudkan pelaksanaan sebuah pekerjaan secara efektif dan efesian dan dapat menentukan terwujudnya hasil yang sukses (usaha yang berhasil).

Dalam Islam, konsep kepemimpinan strategis sudah ada sebelum Mashi, khususnya terkait dengan strategi kesejahtreraan rakyat dalam bidang ketahanan pangan saat negara/wilayah akan menghadapi krisis panjang (7 tahun persiapan dan pertumbuhan, 7 tahun pelaksanan, tahun berikutnya konsistensi dan eksistensi sebuah negara). Hal tersebut terjadi pada masa Nabi Yusuf AS, sebagaimana tercantum dalam al-Quran. Dan atas dasar ini maka tidak salah jika kita mengatakan peletak dasar manajemen atau kepemimpinan strategi yang pertama kali adalah Nabi Yusuf AS.

Dari berbagai konsep dan teori di atas, sangat jelas bahwa kemepimpinan strategi merupakan serangkaian keputusan dan tindakan manejerial yang menentukan kinerja suatu lembaga dalam jangka panjang, baik yang mencakup pengamatan lingkungan, perumusuan strategi, implementasi strategi, serta evaluasi dan pengendalian. Pengembangan dan peningkatan sebuah mutu organisasi atau lembaga bertumpu pada organisasi atau lembaga itu sendiri, mengaplikasikan semua teknik, mendasarkan ketersediaan sember daya, dan pemberdayaan semua komponen terkait secara berkesinambungan akan dapat memenuhi kebutuhan dari masyarakat yang membutuhkan.

Sajian tulisan ini sepenuhnya tidak akan memaparkan tentang kememimpinan strategi secara luas dan menyeluruh, namun sebatas pengenalan konsep yang dikaitkan dengan dunia pendidikan penelaahan dalam kajian keislaman. Untuk itu pada tulisan makalah ini, bahasan yang akan diuraikan meliputi :

1. Bagaimana konsep kepemimpinan strategi

2. Bagaimana kepemimpinan strategi dalam pendidikan

3. Bagaimanan kemepemimpinan strategi Islami.

\section{PEMBAHASAN}

\section{Konsep Kepemimpinan Strategi}

Perkembangan yang terjadi pada berbagai lini kehidupan (profit dan non profit) cendrung menimbulkan permasalahan-permasalahan dan tantangantantangan baru, yang variatif dan intensitasnya cendrung meningkat. Keadaan itu akan membawa dampak yang lebih besar dan luas pada tugas-tugas yang tanggung jawab yang diemban serta bervariasinya sistem yang dibutuhkan. Praktik-praktik kepemimpinan yang selama ini boleh jadi membutuhkan penyempurnaan atau perubahan baik tataran konsep, maumpun implementasi untuk menangani perkembangan yang ada. Untuk itu kebutuhan akan aplikasi konsep Stategic Management \& Stategic Planning sangat aman diperlukan. Hal ini dimaksudkan untuk mengurangi stagnasi sutau lembaga atau organisasi.

Dalam Sedarmayanti

dikemukakan konsep-konsep yang berkaitan dengan konsep strategi untuk dikuasai adalah :

1. Distinctive competence, tindakan yang dilakuan oleh perusahaan agar dapat melakukan kegiatan lebih baik dibandingkan dengan pesaingnya.

2. Competitive adventage, keunggulan bersaing disebabkan pilihan strategi yang dilakukan perusahaan untuk merebut peluang pasar.

3. Strategi fokus, cirinya adalah perusahaan mengkonsentrasikan pada pangsa pasar yang kecil untuk menghindar dari pesaing dengan menggunakan strategi kepemimpinan biaya menyeluruh/ deferensiasi. 
Dari konsep tersebut diartikan bahwa manajemen strategi merupakan sistem dalam satu kesatuan, yang memeliki komponenkomponen yang saling berhubungan, saling mempengaruhi, dan bergerak bersama-sama (secara serentak) ke arah yang sama untuk mencapai tujuan bersama yang telah ditetapkan. Intinya kepemimpinan strategi adalah mengidentifikasi tujuan organisasi, sumber daya organisasi, daan bagaimana pemamfaatan sumber daya yang dimiliki dan yang ada dapat digunakan secara efektif untuk memenuhi tujuan strategi.

Lebih lanjut Edy Mulyasa (2003) mengungkapkan bahwa konsep-konsep dasar tentang manajemen strategis dikemukakan Wheelen and Hunger (1995) sebagai berikut:

a. Manajemen stategis merupakan serangkaian keputusan dan tindakan manajerial yang menentukan kinerja perusahaan dalam jangka panjang, yang meliputi pengamatan lingkungan, perumusan strategi, implementasi strategi, serta evaluasi dan pengendalian.

b. Manajemen strategis menekankan pada pengamatan dan evaluasi kesempatan (opportunity), dan ancaman (threat) lingkungan dipandang dari sudut kekuatan (strength) dan kelemahan (weakness).

c. Keputusan strategis berhubungan dengan masa yang akan datan dan dalam jangka yang panjang untuk organisasi secara keseluruhan dan memiliki tiga karakteristik, yaitu rare, sonsequential, dan directive.

d. Manajemen strategis pada banyak organisasi cendrung dikembangkan dalam empat tahap, mulai dari perencanaan, implementasi, evaluasi, dan pengendalian.

e. Organisasi yang menggunakan manajemen strategi cendrung berkinerja lebih baik.

f. Model manjemen strategis mulai dari pengamatan lingkungan ke perumusan strategi, termasuk penetapan misi, tujuan strategi, dan kebiajakn menuju ke implementasi strategi, termasuk pengembangan program, anggaran, dan prosedur, yang berakhir dengan evaluasi dan pengendalian. g. Perusahaan besar cendrung memeliki tigal level strategi, yang berintraksi dan terintegrasi dengan baik untuk keberhasilan perusahaan.

Dengan semua konsep yang ada tentang strategi di atas yang dikemukakan bahkan yang dikembangkan oleh para pakar diharapkan kedepan suatu lembaga atau organisasi dapat berkembang lebih baik dan maju serta dapat mempertahankan keunggulannya secara kompetitif dan dapat bersaing lebih maju serta lebih baik dari lembaga atau organisasi lainnya yang dijadikan sebagai pesaing atau mitra. Keunggulan kompetitif ini hendaknya berkelanjutan dengan terus-menerus beradaftasi pada perubahan-perubahan dan perkembangan dalam tren serta kegiatan eksternal, konpetensi dan sumber daya internal, disamping itu penarapan strategi dan nilai-nilai strategi secara konsisten akan dapat memperkokoh kepemimpinan strategi.

Sejalan dengan konsep manajemen strategi yang senantiasa selalu menyikapi dinamika (perubahan dan perkembangan) yang terjadi pada lingkungan lembaga atau organisasi, dapat dikemukakan bahwa karakteristik manajemen strategi ini sebagaimana pendapat Sedarmayanti (2014) adalah sebagai berikut :

1. Bersifat jangka panjang.

2. Bersifat dinamik.

3. Merupakan sesuatu yang terpadu oleh manajemen operasional.

4. Perlu dimotori oleh unsur pada manajer tingkat puncak.

5. Berorientasi dan mendekati untuk masa depan.

6. Senantiasa harus didorong dan didukung dalam pelaksanaan oleh semua sumber daya ekonomi yang tersedia.

Selanjutnya berkaitan dengan langkah model manajemen strategi sebagaimana konsep J. David dalam Sedarmayanti (2014) yaitu (1) Pengamatan lingkungan eksternal (lingkungan sosial yaitu potensi yang ada dan lingkungan tugas yaitu budaya kerja organsasi yang berjalan) dan internal (struktur budaya sumber daya yaitu prosedur dan wewenang). 
Perumusan strategi yang meliputi penyusunan misi, tujuan, strategi (langkah-langkah operasional) dan kebijakan. (3) Implementasi strategi yang meliputi pelaksanaan program, pelaksanaan dan penyesuaian anggaran, prosedur (pelaksanaan proses tang teratur dan berkesinambungan dengan mekanisme kerja yang tepat) yang mengarah kepada kepuasan pelaggan dengan pelayanan prima. (4) Evaluasi dan Pengendalian terhadap kinerja semua komponennya.

\section{Implementasi Manajemen Strategi dalam Pendidikan}

Umunya istilah strategi lebih sering diasumsikan pada bidang ekonomi yang berorientasi pada bisnis (profit) baik pengembangannya secara teoritis maupun praktis. Dan hal ini sudah berlangsung sangat lama. Adapun pada lingkup non bisnis (non profit) seperti dunia pendidikan, istilah strategi merupakan paradigma baru.

Dengan demikian, menurut Sanusi Uwes (2017) jika diimplementasikan pada lingkungan organisasi pendidikan, dalam manajemen strategi tidak mungkin dilakukan sebagai kegiatan pengambilalihan seluruh kegiatannya sebagaimana dilaksanakan dilingkungan organisasi profit (bisnis) dari kedua organisasi tersebut berbeda dalam banyak aspek terutama falsafah yang mendasarinya dan tujuan yang hendak dicapai.

Perbedaan dalam implementasi strategi dalam dunia bisnis didasari pada falsafah nilainilai persaingan bebas antar organisasi (perusahaan) bisnis sejenis dengan pendayagunaan sumber daya yang dimiliki untuk mencapai tujuan strategi. Adapaun tujuannya adalah mempertahankan dan mengembangkan eksistensi masing-masing organisasi perusahaan bisnis untuk jangka waktu yang panjang, dan upaya untuk memperoleh laba (keuntungan) kompetitif secara bekerlanjutan. Sehingga sistem pelaksanaan pasar secara kapitalis, liberalis, oppurtunis selalu kedepankan, dan sosialis serta humanis menjadi hal yang dikesampingkan. Sedangkan pada organisasi pendidikan didasari oleh falsafah nilai-nilai kemanusian, kesatuan, dan pengabdian untuk mencerdaskan kehidupan manusia, dan merubah karakter pribadi manusia.

Disampim itu dalam sistem pengorganisasian strategis bisnis (profit) suatu perusahaan mempunyai otonomi dalam menjalankan manajemennya, yaitu kebebasan dalam mewujudkan pengembangan organisasinya dengan cara memilih, mangatur strategi manakah yang terbaik untuk perusahaannya. Sementara dalam organisasi non profit dalam hal ini lembaga pendidikan, sistem manajemennya sudah diatur secara umum oleh pemerintah pusat maupun daerah, secara berencana dan sistematis dalam bentuk aturan-aturan yang terikat dalam mengimplementasikan manajemennya.

Dalam kaitannya dengan organisasi pendidikan, Hidari Nawawi dalam Sanusi Uwes (2017) mengungkapkan bahwa pengertian manajemen strategi ada empat yaitu :

1. Proses kegiatan pengambilan keputusan

Manajemen strategi adalah proses atau rangkaian kegiatan pengambilan keputusan yang bersifat mendasardan menyeluruh, disertai penetapan cara pelaksanaannya, yang dibuat oleh manajemen puncak, dimplementasikan oleh seluruh jajaran di dalam suatu organisasi untuk mencapai tujuan.

Dari pengertian tersebut terdapat beberapa aspek penting, yaitu :

a) Manajemen strategi merupakan proses pengambilan keputusan.

b) Keputusan yang ditetapkan bersifat mendasar dan menyeluruh, yang berarti berkenaan dengan aspek-aspek yang penting dalam kehidupan sebuah organisasi, terutama tujuan dan cara melaksanakan atau cara mencapainya.

c) Pembuatan keputusan tersebut harus dilakukan sekurang-kurangnya melibatkan pimpinan puncak (kepala sekolah), sebagai penganggung jawab utama pada keberhasilan atau kegagalan organisasi.

d) Pengimplementasian keputusan tersebut sebagai trategi organisasi untuk mencapai tujuan strateginya dilakukan 
oleh seluruh jajaran organisasi (warga sekolah) sehingga dapat menjalankan peranan sesuai dengan kewenangan dan tanggung jawab masing-masing.

e) Keputusan yang ditetapkan manajemen puncak (kepala sekolah) harus diimplementasikan oleh seluruh warga sekolah dalam bentuk kegiatan/pelaksanaan pekerjaan yang terarah pada tujuan strategi organisasi.

2. Usaha-usaha manajerial untuk menumbuhkembangkan kekuatan organisasi.

Dalam pengertian ini kepala sekolah dengan atau tanpa bantuan manajer bawahannya (Wakasek, Pembina, Kepala Tata Usaha), harus mengenali aspek-aspek kekuatan organisasi yang sesuai dengan misinya, yang harus ditumbuhkembangkan untuk mencapai tujuan strategi yang telah ditetapkan. Dan setiap peluang atau kesempatan yang terbuka harus dimamfaatkan secara optimal.

3. Arus keputusan dan tindakan yang mengarah pada pengembangan strategi yang efektif

Pengertian ini menekankan bahwa arus keputusan dari para pimpinan organisasi (kepala dinas, kepala sekolah) dan tindakan berupa pelaksanaan keputusa, harus menghasilkan satu atau lebih strategis sehingga dapat memilih yang paling efektif atau yang paling andal dalam usaha mencapai tujuan organisasi pendidikan.

4. Perencanaan berskala besar.

Pengertian ini berorientasi pada jangkauan masa depan yang jauh (visi) dan ditetapkan sebagai keputusan manajemen puncak (keputusan yang bersifat mendasar dan prinsipil), agar memungkinkan organisasi berintraksi secara efektif (misi) dalam usaha menghasilkan sesuatu (perencanaan operasional) yang berkualitas, dengan diarahkan pada optimalisasi pencapaian tujuan (tujuan strategi) dan berbagai sasaran (tujuan operasional) organisasi.

Dari pengertian di atas yang cukup luas dapat disimpulkan bahwa manajemen strategi merupakan suatu sistem satu kesatuan yang memiliki komponen-komponen yang saling berkaitan pada sistem perencanaan, sistem operasional, sistem evaluasi dan sistem pengendalian. Semua komponen kesatuan ini dituangkan dalam rencana strategis (RENSTRA) dan rencana operasional (RENOP) suatu lembaga pendidikan.

Beni Ahmad Saebani (2016) menjelaskan bahwa salah satu model perencanaan pendidikan adalah perencanaan strategi, yaitu perencanaan strategi yang difokuskan pada tujuan sfesifik yang memuat unsur-unsur: (a) perumusan visi dan misi, (b) pengkajian lingkungan eksternal, (c) pengkajian lingkungan internal, (d) perumusan isu-isu strategi, (e) penyusunan strategi. Perencanaan strategis berusaha menyelesaikan permasalahan pendidikan untuk jangka waktu yang panjang.

Pelaksanaan kepemimpinan strategis dalam organisasi pendidikan mempunyai keunggulan-keunggulan tersendiri dalam pelaksanaannya di lingkungan oraganisasi pendidikan apabila dilaksanakan dengan komitmet dan konsisten, karena kepemimpinan strategis mengatur berbagai dimensi pengelolaan lembaga, juga mengatur liingkup yang terkait dengan lembaga itu sendiri baik pada bidangnya maupun lingkungannya.

\section{Kepemimpinan (manajemen) Strategi Islami}

Suatu organisasi tentunya memiliki tujuan, dan untuk mencapai tujuan tersebut dibutuhkan perencanaan (manajemen). Dalam hal ini perencanaan adalah teknis bagaimana mempersiapkan langkah-langkah selanjutnya untuk menghadapi langkah selanjutnya. Dengan kata lain perencanaan adalah langkah-langkah strategi untuk mencapai tujuan. Karena perencanaan merupakan hal yang strategi, maka hakikatnya dari sebuah perencanaan adalah kegiatan untuk merumuskan tujuan yang akan dicapai, cara pencapaiannya, dan perangkat yang dibutuhkan untuk mencapainya. Dalam Islam menyusun suatu perencanaan yang akan datang sudah dijelaskan dalam Al-Quran QS. Al-Hasyr ayat 18, dan QS. An-Nisa ayat 9. 
Dalam Islam konsep perencanaan dapat diadopsi dari konsep taqdir. Taqdir didefinisikan dengan ketentuan yang digariskan Allah sebelum terjadinya suatu peristiwa. Dengan kata lain taqdir merupakan rencana Allah SWT yang dibuat untuk alam semesta. Dalam perkara ini tadir memiliki paling tidak tiga makna serumpun yaitu :

1. Ukuran, sebagaimana terdpat dalam QS. Al-Furqan ayat 2 :

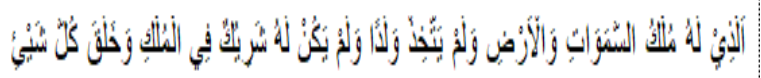

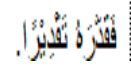

Artinya : "Kepunyaan-Nya lah kerajaan langi dan bumi, dan Dia tidak memiliki anak, dan tidak ada sekutu bagi-Nya dalam kekuasaan (Nya), dan dia telah menciptakan segala sesuatu, dan Dia menetapkan ukuran dengan serapi-rapinya".

Dalam ayat lain pada QS. Al-Qomar ayat 49 juga di sebutkan :

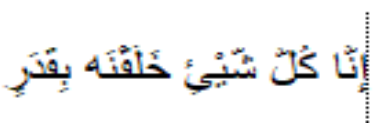

Artinya: "Sesungguhnya Kami menciptakan segala sesuatu menurut ukuran".

2. Sempit, yang terdapat salah satunya pada QS. Al-Ra'd ayat 26 :

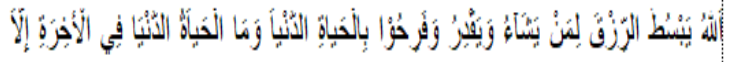

Artinya: "Allah meluaskan (melapangkan) rizki dan menyempitkannya bagi siapa yang Dia kehendaki, mereka bergembira dengan kehidupan dunia, padahal kehidupan dunia hanyalah kesenangan (yang sedikit) dibanding kehidupan akhirat"

3. Mulia dan terhormat, sebagaimana terdapat dalam QS. Al-An'am ayat 91 :

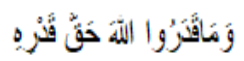

Artinya: "Dan mereka tidak menghormati Allah dengan penghormatan yang semestinya..."

Ketiga makna di atas, ukuran, sempit dan mulia merupakan indikator sebuah perencanaan atau sebuah manajemen dan sebuah kepemimpinan. Yaitu perencanaan yang baik adalah yang terukur (Profitabilitas), memiliki tahapan yang jelas (tidak ada ruang

Jurnal Pendidikan Mandala kosong) atau waktu yang sia-sia (produktifitas tinggi), dan mencapai tujuan yang diinginkan (kemulian dan kehormatan) atau positif kompetitif.

Dalam persefektif waktu pada makna taqdir, manajemen strategi dalam islam setidaknya mengarah 4 hal yaitu Taqdir Azaliy (jangka panjang yang terus menerus), Taqdir Umury (Jangka panjang sampai batas umur/usia), Taqdir Sanawiy (jangka menengah), Taqdir Yaumiy (jangka pendek), atau dalam lingkup administrasi pendidikan dikenal dengan istilah program tahunan, program semester, program mingguan, dan program harian.

Semua konsep dan prinsip dalam kepemimpinan Islam menekankan pada keyakinan bahwa manusia diperintahkan membuat rencana, mengupayakan, sedangkan keberhasilan dari rencana dan usaha tersebut merupakan kehendak Allah SWT.

Islam sebagai suatu sistem yang sempurna tentu saja memiliki konsep pemikiran tentang manajemen. Menurut Didin dan Hendri dalam Asep Efendi (2018) tentang konsep manajemen Insya Allah, manajemen bisa dikatakan telah memenuhi insya Allah apabila: Pertama, manajemen ini mementingkan perilaku yang terkait dengan nilai-nilai keimanan dan ketauhidan. Kedua, manajemen insya Allah pun mementigkan adanya struktur organisasi (QS. Al-Mujadalah ayat 11) yang menjelaskan bahwa dalam mengatur dunia, peranan manusia tidak akan sama. Ketiga, manajemen insya Allah membahas soal sistem. Sistem ini disusun agar perilaku didalamnya berjalan dengan baik.

$$
\text { Menurut Asep Efendi (2018) }
$$
manajemen strategis dalam perspektif Islam, iadalah rangkaian proses aktivitas manajemen islami yang mencakup: (1) tahapan analisis lingkungan organisasi, (2) formulasi strategi, (3) implementasi strategi, (4) evaluasi dan kontrol terhadap keputusankeputusan strategi organisasi yang memungkinkan pencapain tujuan di masa depan. 
Lebih lanjut diungkapkan bahwa implemntasi manajemen strategi dengan kendali syraiah akan membawa organisasi bisnis berorientasi pada pencapaian empat hal utama yaitu 1. Target hasil (profit materi dan banefit non materi); 2. Pertumbuhan (terus meningkat); 3. Keberlangsungan (dalam kurun waktu selama mungkin); 4. Keberkahan dan keridhaan Allah.

Pelaksanaan kepemimpinan strategi secara Islami akan memberikan dampak dan energi postif dalam meraih ridha Allah SWT.

\section{PENUTUP}

Kepemimpinan strategi merupakan suatu upaya pengelolaan yang terencana dalam menjalankan suatu organisasi. Strategi meliputi merencanakan, mengorganisir, mengarahkan, mengkordinir serta mengawasi menindak lanjutan kegiatan dalam suatu organisasi agar tercapai tujuan organisasi secara efisien dan efektif. Dan lebih utama bernilai ibdah mencapai kemulian, kehormatan, serta keridhaan Allah SWT.

Untuk mencapai hal tersebut pemamfataan dan pemberdayaan sumber daya dalam konsep Islam tetap ditegakkan untuk pertumbuhan rohani dan jasmani secara berimbang pada personal-personal komponen (steakholders) yang terkait agar ia berkembang secara maksimal sesuai dengan ajaran Islam .

Kepemimpinan dalam Islam terkait dengan masuliyah (tanggung jawab), tidak saja tanggung jawab kepada manusia (bawahan) tapi juga tanggung jawab kepada Allah. Rasulullah SAW bersabda yang artinya; "setiap kalian adalah pemimpin dan masingmasing kalian akan mempertanggungjawabkan atas kepemimpinannya" (HR. Bukhari-Muslim). Implementasi kepememimpinan ini dapat dijabarkan dalam dua fungsi utama yaitu fungsi pemecahan masalah (pemberi solusi) yang meliputi pemberian pendapat, informasi, solusi dari suatu problem yang selalu didasarkan pada syariah (Coaching - mentory, Conselling - Cedowing), fungsi ini juga diarahkan untuk memberikan motivasi ruhiyah kepada para SDM organisasi. Dan fungsi sosial (fasilitator) berhubungan dengan interaksi antar anggota komunitas dalam menjaga suasana kebersamaan tim agar tetap solid. Initeraksi dalam tim ini tetap dalam koridor amar ma'ruf nahi mungkar.

Jadi semua kegiataan aspek kepemimpinan strategis tetap dalam kendali Islam dengan berpedoman pada sumber hukum-hukumnya.

\section{DAFTAR PUSTAKA}

-------, Al-Quran dan Terjemahannya, Kementerian Agama, Jakarta, 2010

Ansori, Muhammad, Sejarah Strategi: Dasar Prinsip dan Pengembangan, https://strategiusaha.wordpress.com .2010

Efendi, Asep, dkk., Manajemen Insya Allah, Jakarta, Amzah, 2018

Mulyasa, Edy, Menjadi Kepala Sekolah Profesional dalam Konteks Menyukseskan MBS dan KBK, Remaja Rosda Karya, Bandung, 2003

Purnomo, Setiawan Hari dan Zulkieflimansyah, Manajemen Strategi Sebuah Konsep Pengantar. Jakarta, Fakultas Ekonomi Universitas Indonesia, 2005.

Saputra, Nurul, Perkembangan Strategi Pemasaran,

https://rocketmanajemen.com, 5 Juli 2018

Sedarmayanti, Manajemen Strategi, Refika Aditama, Bandung, 2014.

Saebani, Beni Ahmad dan Koko Kamaruddin, Filsafat Manajemen Pendidikan" Pustaka Setia, Bandung, 2016

Uwes, Sanusi dan A. Rasdiana, Sistem Pemikiaran Manajemen Pendidikan, Pustaka Setia, Bandung, 2017 